\title{
Urban Farming as Women Empowerment: Case Study Sa'uyunan Sarijadi Women's Farmer Group in Bandung City
}

\author{
Kinanti Indah Safitri ${ }^{*}$ Oekan S Abdoellah ${ }^{2,3}$, and Budhi Gunawan ${ }^{3}$ \\ ${ }^{1}$ Environment Science Program, Postgraduate School, Universitas Padjadjaran, Indonesia \\ ${ }^{2}$ Center for Environment and Sustainability Science, Universitas Padjadjaran, Indonesia \\ ${ }^{3}$ Department of Anthropology, Faculty of Social and Political Sciences, Universitas Padjadjaran
}

\begin{abstract}
Urban farming activity in Bandung City contains an idea of women empowerment. That is because urban farming has done a lot by housewife. The Bandung City Government attempts to implement gender mainstreaming program in the development through urban farming. Therefore, an urban farming program in Bandung City designed by local government nowadays has four women's farmer group. One of the women's farmer group is Sa'uyunan Sarijadi. This research uses a case study from Sa'uyunan Sarijadi Women's Farmer Group in Bandung, Indonesia. This study discusses the implementation urban farming as women empowerment in Sa'uyunan Sarijadi Women's Farmer Group. The results showed that all of the members are involved in various production activities such as seeding, maintenance, hydroponic management for making herbal medicinal products derived from medicinal plants from the garden they plant. The sa'uyunan sarijadi women's farmer group develop the creativity of housewives in carrying out agricultural production activities and making processed products from food crops. The motivation of women to be active in the management of urban farming because of the awareness to present organic and hygienic food consumption. Besides, the benefit of urban farming has provided economic benefits, social networks, and knowledge about providing healthy food.
\end{abstract}

\section{Introduction}

Based on data from the Food and Agricultural Organization (FAO), the world's population in 2050 is projected to reach 9.7 billion. The rapid population growth requires sustainable food consumption which agriculture must be able to meet [18]. This is because several studies have shown that high population growth can potentially lead to food insecurity $[9,12]$. Urban food insecurity in low-income countries is higher (50\%) than levels in rural areas (43\%) [25]. For supporting food needs for urban communities, the local government in many countries implement urban farming strategy by involving the role of urban women.

Urban women in many countries bear the responsibility for the survival and welfare of the household [13]. Women have concerns about providing food for their families so they choose to farm organically [21]. In addition, women in urban areas have the potential to become actors managing urban farming because this activity can be carried out in areas close to urban settlements, and often can be applied in backyards, rooftops, and abandoned land around houses. Managing urban agriculture can be integrated with other household responsibilities [11]. Thus, women are an important part of urban farmers because they tend to have the responsibility to provide family food consumption [27].
The role of women in urban agriculture is not only to ensure family food security but also to increase income. Women farmers can make money by selling excess products from urban farming activities. Women use the income from urban farming to finance various needs such as housing loans, sanitation maintenance and agricultural production costs [21]. Therefore, urban agriculture can be a safety net for poor households who want to increase their income [11].

However, there were various obstacles faced by women in carrying out urban agricultural activities, especially urban farming. Women face difficulties in accessing resources that have the potential to prevent them from contributing further to urban agriculture [27]. Women farmers tend to experience difficulties in accessing, using and or controlling land in cities compared to men farmer [11]. Another study from Adedayo \& Tunde (2013) states that women farmers are faced with a various of challenges such as a lack of credit facilities, accessibility to limited land, agricultural inputs, poor terrain and lack of extension services. From various problems, some of which are caused by gender dynamics in a region [11]. Thus, agricultural development policies should emphasize the provision of facilities that ensure gender equality in access to and control over production resources [7]

Nowadays, the international food organization (FAO) and the local government has begun to pay attention to aspects of gender mainstreaming in the

\footnotetext{
*Corresponding author: Kinantiindahsafitri@gmail.com
} 
implementation of the agricultural policy of the city. One case occur in Bandung City, West Java, Indonesia, where urban agriculture into city government official program through the Department of Food and Agriculture. The Food and Agriculture Office of Bandung City has implemented sustainable agricultural management by optimizing gender mainstreaming through the group of women farmers to manage the Sustainable Food House Area.

Therefore, Urban farming activity in Bandung City contains an idea of women empowerment. Women empowerment is oriented as the basis for sustainable development according to the UN Agenda 21 in 1992 [17]. Therefore, this article seeks to discuss the phenomenon of the emergence of women farmers group as an urban women's empowerment scheme. The researchers raise a case study in the Sauyunan Women Farmer Group in Bandung, which is a pilot women farmer group with clear community empowerment stages. The results of this study are expected to be a benchmark for the success of a women's empowerment program that is able to synergize with other cross-sector development programs.

\section{Literature Review}

Women empowerment is a process by which women gain more control over resources (income, knowledge, information and technology) [24]. Empowerment is a very popular term to be used in highlighting various phenomena such as women's empowerment [16], community empowerment [14], empowerment of marginalized communities [15] and others [6]. Several stages in the empowerment process [22] include:

\section{Awareness Phase}

The community is positioned as the subject of empowerment. The community must understand and be aware of the problems that occur in their environment and the nature of the empowerment program which is implemented of course with assistance from external parties. The program carried out for example is providing knowledge that is cognition, belief, and healing.

2. Ability Transformation Phase

The ability transformation stage means capacitating humans in the context of individuals and groups. After the community begins to realize and be able to identify existing problems and potentials, the next phase is the provision of abilities and expertise and knowledge. This is to make the empowerment subject competent in managing the work which they are responsible.

\section{Delegation of Authority Phase}

The delegation of authority phase is applied after the community is deemed ready to carry out the empowerment program independently. The provision of power or authority to the community is aimed the community able to cultivate their potential and be able to carry out the program in a sustainable manner even without intervention from external parties.

At the level of concept empowering the farmer community, it means giving the ability to the farmer community to empowered, have power in the social, political and economic dimensions. The target of empowerment is vulnerable groups. Women in the agricultural sector can potentially be included in the vulnerable group because changes related to liberalization and marketisation are seen as playing an important role in marginalizing women from natural resources when community-based tenure systems are shifted to a system of control that is commoditized and individualized, thereby reducing women's access to land and water as community members (Tsikata and Golah, 2015; Ahlers and Zwarteveen 2009 in Elmhirst, 2015) Women who live in poverty conditions are vulnerable to becoming victims of exploitation to fulfill their economic needs. They are trapped in an unfit work sector. Therefore, women who carry out farming activities face various problems that become obstacles for them to develop agricultural activities (Logeswari and Thiruchenduran, 2016).

However, there is another perpective that sustainable agriculture can be a new space for empowerment and resistance where women and agricultural work become seen and valued [26]. So this perspective leads to the conclusion that agriculture may be related to liberating women from oppressive gender relations and changing the type of work they do [2].

Referring Micheletti (2004), it is emphasized that women are more involved in providing household consumption because they are often involved in daily spending, so the issue of food safety such as the use of pesticides and other hazardous substances is a problem that is widely understood by women [23]. The role of women in sustainable agricultural management is needed because urban women are consumers who are quite skeptical of the vegetables and fruit that are on the city market related to the content of pesticides and drug mixtures. Therefore, they prefer to grow their food crops by utilizing the remaining land around the house. In Addition, Maxwell (1995) describes some of the motives of married women to do outside agriculture to increase food supplies.

1. Farming meshes well with other expected household tasks, especially cooking and child care.

2. Some women have businesses that rely on agricultural products, such as selling food.

3. Farming is a source of income that can be used to meet household needs.

\section{Methods}

\subsection{Description of Study Area}

This research was conducted in Bandung city which is the capital of the province of West Java. Based on Bandung City Government data, the area of Bandung city reaches 16,731 hectares which include 30 Districts, 151 Sub-districts, 1561 hamlets and 9691 neighbourhoods. The City of Bandung is astronomically located at $107^{\circ} 32^{\prime} 38.91^{\prime \prime}$ East Longitude and $60^{\circ} 55^{\prime}$ 19.94 " South Latitude. Administrative boundaries of Bandung City include: In the north, it is bordered by 
Lembang and Cisarua Subdistricts. It is bordered by Cileunyi District in the east. In the west, it is bordered by Cimahi City and Padalarang Districts and it is bordered by Dayeuhkolot District and Bojongsoang District in the south. In this research focused observe women empowerment in urban farming group by taking case study of research is Sa'uyunan Women Farmer Group at Sarijadi. Sa'uyunan Women Farmer Group is an organization of women engaged in urban farming that formed the Department of Food and Agriculture Bandung. Women Farmer Sa'uyunan initiate urban farming since 2016. All the members come from the housewife who lived in the village Sarijadi. At present, there are 46 members of women farmer group. Sa'uyunan Women Farmer Group has been the target group of the Department of Food and Agriculture Bandung. In this group, all the members are involved in various production activities such as: seeding, maintenance, hydroponic management to making herbal medicinal products derived from medicinal plants from the garden they plant. Now the Sa'uyunan Women's Farmer Group has developed as a pilot group about empowering women in agriculture.

\subsection{Research Implementation Method}

This research uses a descriptive qualitative approach. Descriptive qualitative approach is suitable for use in qualitative type research as a theoretical lens or perspective to guide related research on gender, class and race [3]. This is because researchers use gender mainstreaming in analyzing the process of women empowerment in urban farming group. The researchers use a tool to analyze women empowerment based on: Awareness Improvement, Ability Transformation, and Delegation of Authority. In this case study, several important informants will be selected who comprehensively understand the process of women empowerment as well as being cooperative in providing information. The size of the informants taken is determined from the saturation of the data in the concept of theoretical saturation [8].This research was conducted from August 2020-October 2020. Totally, researcher interview 22 women farmers and 3 staff local governments from Food and Agriculture Department of Bandung City.

Data collection techniques using literature study methods through:

1. Study of literature in the form of books, journals, scientific articles relating to the empowerment of women in urban agriculture

2. Observation through direct observation of women who carry out urban farming activities and become a source of income and food security for their families. Researchers observed directly, strategies of women farmer in carrying out agricultural production activities together with members of groups that are dominated by men. Researchers identified the division of work carried out by women in the garden. We also observe the results of production activities that have been carried out by women farmer such as the results of seeding plants and women's activities in providing plant nutrition.

3. Interviews are useful in collecting in-depth data to explore the process of women empowerment in urban farming. Aspects that will be examined include the role of Department of Bandung City in empowering urban farming group.
4. Documentation: Collecting documentation data by accumulating images, recordings, and videos. This documentation is used as a tool to analyze the situation in the land, rooftop, house yard, and green house.

\section{Results}

Urban farming in Bandung City was initiated as an official program of the Food and Agriculture Office since 2014. In 2020, there are 144 urban farming groups under the auspices of the Bandung Food and Agriculture Office. All of the members are involved in various production activities such as seeding, maintenance, hydroponic management to making herbal medicinal products derived from medicinal plants from the garden they plant. Bandung City Government attempts to implement gender mainstreaming program in the development. The involvement of women in the success of sustainable development programs is important in the context of developing countries. For this reason, intervention by the government and community organizations is needed through empowerment internalization.

Urban farming becomes one of the actualizations of gender mainstreaming program through empowerment. Therefore, an urban farming program in Bandung City designed by local government nowadays has women's farmer group. The women farmer tends to have knowledge about food prices. It is because they directly create interaction with food market. Based on researchers interview with organic vegetable shop owner, organic products sold in one of the specialties organic stores, for example, the price of organic noodles reached Rp. 20,000 per package while non-organic products were only Rp. 2,500. Therefore, awareness of housewives to bring consumption of healthy food is still only realized by some women who live above the poverty line. Whereas for people who live below the poverty threshold, most of them are migrants who are urbanizing, it is quite difficult to consume organic products. These migrants had not yet had a permanent home Bandung City. The house they live in is still renting, so it is quite difficult to carry out the process of farming in the city without ownership of land or private homes.

While the guarantee given by women farmers in Bandung regarding organic plants is to offer guaranteed healthy food. They are aware that consuming food that is continuously given chemical intervention will have an impact on the health of all family members. Therefore, they have enthusiasm for practice urban farming. With the increasingly easy means of communication, community groups who are members of the smartphone chat application group can share information and knowledge related to the organic production process independently.

Sauyunan Farmers' Group is one of the women farmer groups officially under the auspices of the Bandung City Food and Agriculture Office. This group comes from members of the Family Welfare Empowerment Movement Team, 03rd Hamlet, Sukawarna Urban Village. The existence of this group 
began with the appointment of the Family Welfare Empowerment Movement Team as a representative for the Participants in the Bejo Herbal Park and Urban Farming competitions in 2016 which was organized by the West Java Tribun. The competition, which was attended by the Family Welfare Empowerment Movement Team, resulted in support from the urban village so that various gardening facilities such as seeds, fertilizers, and polybacks were provided to the Family Welfare Empowerment Movement Team to renovate their area to make it fresher. The Family Welfare Empowerment Movement Team 03rd Hamlet, won the favorite winner of the competition so that it sparked interest from group members to continue planting activities.

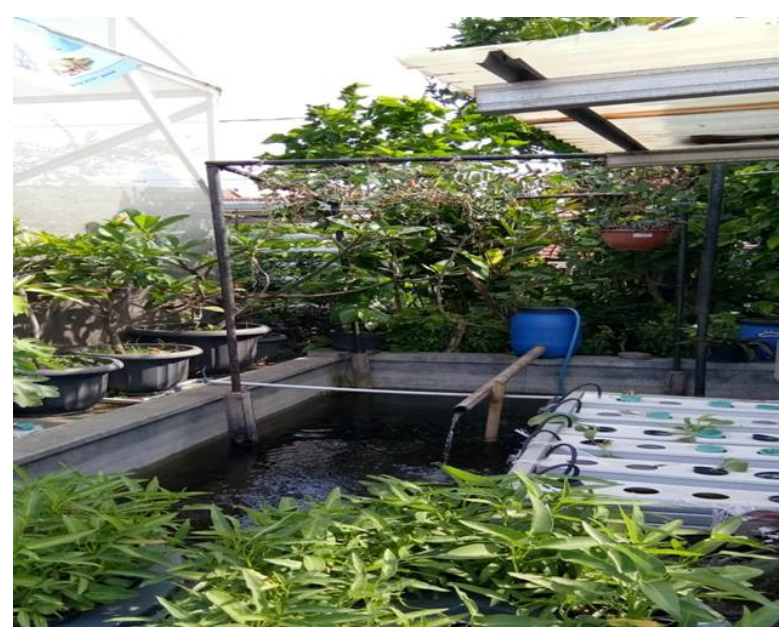

Figure 1. Sa'uyunan's Garden

Currently Sa'uyunan Women Farmer Group, the group has been able to produce food independently. Through various types of training, education and monitoring by the government, they become a Women Farmer Group that can produce certain types of plants and sell them to other areas. Based on the experience and skills of the group Mrs. Enok Rosmanah as group leader can guide the women in her group to become independent in food management. Members of the Sa'uyunan women farmer group already have an orientation on health aspects for family consumption. Activities at the Women Farmer Group start from making fertilizers, restoring seeds, arranging planting locations, managing waste, distributing it to making their products which are marketed to elementary school students who are close to their farming areas. Most interestingly, they make collaborative programs with schools to introduce planting plants in the school environment for children.

Based on Nugroho \& Wrihatnolo (2007), the process of empowering women farmer in the Sauyunan Farmer Group can be described in three phase, namely:

\section{- Awareness Phase}

Awareness phase by raising awareness from women urban farmers. There are facilitators from the Food and Agriculture Office of Bandung City who also assist urban farmers to encourage their enthusiasm for gardening. This is carried out to intervene women farmer so that they can continuously control the garden and carry out various innovative agricultural activities. The Food and Agriculture Office of Bandung City also provides seeding homes, nursery and fish pond. In addition, the land used for the Sa'uyunan farmer's garden is land belonging to the City Government which is the remaining parking lot. The sauyunan women farmer group that are assisted by the Food and Agriculture Office of Bandung City must make activity, financial, and cooperation reports every month. This also applies to other urban farming groups that are under the guidance of The Food and Agriculture Office of Bandung City. Inactive urban farming groups will be excluded from the beneficiary list. Several informants interviewed by researchers stated that the formation of the Sauyunan motives for being involved in the Sauyunan women farmer group were mainly to actualize their hobbies.

Therefore, it is necessary to raise awareness so that there are various strong motivations that motivate urban women to be involved in agriculture. The phase of empowerment carried out include awareness efforts through communication forum media. The awareness phase aims to increase people's sensitivity to problems that occur in the city. Generally, the facilitator brings up a common issue that becomes a problem in the city, namely the importance of ensuring safe and healthy food consumption in the household.

In addition, the facilitator also provides encouragement by socializing the benefits of urban farming: actualizing the hobby of farming, making food and salary, and social networking. So far, The benefits gained by women in the Sa'uyunan women farmer group include benefits for actualizing the hobbies of farming, making food, and associating. They can fill their free time when they are finished with housework because the majority of the female actors involved are housewives. The Food and Agriculture Office is also implementing a strategy to increase the interest of the city community in planting by holding the Bandung Agri Market. Bandung Agri Market is an activity that serves as a marketing medium for crops and UMKM products created by the urban farming group that is under the guidance of the Bandung City Food and Agriculture Office. With the existence of Bandung Agri Market, it is expected that the members of the urban farming group that have been formed can build enthusiasm to maintain the group's production activities. So that the economic side of urban farming activities can be felt by urban farmers.

- Ability Transformation Phase

The second phase is capacity building through training to build group institutions. This is because the aspect of empowerment for women should not only be related to economic activities to improve their standard of living but also to social and cultural aspects through capacity and skill building and encouraging the existence of social institutions that become a forum for women to create network wider. Building group institution is carried out through communication forum to strengthen relationship among members and build network or networking with other women farmers. In addition, the formation of groups is believed to facilitate capacity building for increase the potential of farmers related to business management science and also 
training in to make various processed products from gardening

After the institution was formed, the transfer of knowledge from technical assistance began to be carried out to develop post-harvest businesses through various training and education. The sauyunan women's farmer group implements an integrated farming system that not only grows horticulture and medicinal plants but is also trained in the cultivation of catfish in buckets and raising small sccale livestock

The target expected by the Food and Agriculture Agency and community leaders of Sarijadi District, the Sa'uyunan Women's Farmer Group is not only selling their crops but also processing products from the harvest. These processed products include: making red spinach chips, red spinach peanut brittle, kale peanut brittle, and vegetable juice. Thus, Sauyunan women farmer can develop their own creativity in carrying out agricultural production activities and when making processed products launching through these two marketing methods.

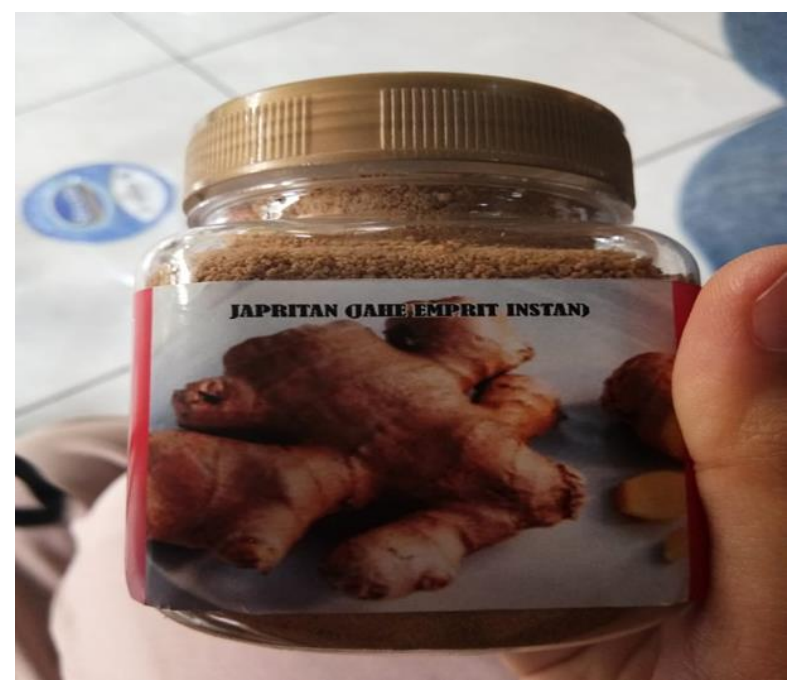

Figure 2. Sauyunan's Product

- Delegation of Authority Phase

The third phase is delegation of authority. The delegation of authority in the sauyunan women farmer group is carried out by forming divisions in the group to maximize the role of each member functionally. The group divides 4 sub-organizational units, including: the urban farming unit, the herbal unit, the facilities and infrastructure unit and the production unit. The following is a description of each unit:

- Urban Farming unit: Managing the Technical of Vegetable Production

- Herbal unit: Making Herbal Products

- Facilities and infrastructure unit: Selling Fertilizer, Selling Lembang Soil and Vegetable Sales Operations

- Production unit: Making Food and Beverages from Sa'uyunan Women Farmer Garden.

All of the members are involved in various activities such as making fertilizers, restoring seeds, arranging planting locations, managing waste, promoting their products, and making herbal products. Sa'uyunan
Women Farmer group also doubles as the Manager of the Sustainable Green Waste Bank, Integrated Healthcare Center, and Integrated Development Post.

In the Sa'uyunan Women Farmer Group, women are not awkward to actively describe their opinions and carry out their agricultural activities. But decisions that are mutually agreed upon are often influenced by the Bandung Food and Agriculture Office. Many program innovations were also derived from the Local Government. The role of local government extension officers is very important to provide input in decision making.

In this stage of delegation of authority, the launch of sauyunan products was also started and began to promote the sauyunan gardening urban villages so that they could become educational tours. Promotion of urban village gardening and processed products has taken advantage of social media.

In the era of modernity, communication technology using the internet has become a tool to support performance in marketing management. The sophistication of online media has shifted human communication patterns towards changing virtual interactions. Sa'uyunan farmer members are also given an authority to market diversified processed plant products on various social media. So far, marketing using social media has been carried out through the personal Whatsapp share stories feature of each Sauyunan member

\section{Conclusion}

Urban farming is a potential program to achieve the 11th SDGs target in 2030, which is to manage sustainable slums and manage urbanization which is part of urban settlement planning through women empowerment. The relationship between urban agriculture and urban poverty is indeed not direct, but urban agriculture can be a solution for poverty and achieve urban food needs, considering that urban agriculture can encourage small businesses, selling vegetables, and compost [4]. Bandung City has a phenomenon of conversion of agricultural lands, but this phenomenon can be resolved through urban farming. Bandung City can be a role model in the management of urban farming in various cities in Indonesia. Urban farming can be replicated without a large area of land because the method applied does not require large areas. So, it can be the food fulfill of the household itself. The methods carried out by women in urban farmers include horticulture, hydropower, rooftop, aquaponics.

For supporting the success of the urban farming program, the Bandung City Government applies aspects of gender mainstreaming. Thus, empowering women is crucial to hone the self-competence needed to equip women's skills and produce human resource output that is capable of taking a role in the dimensions of global life. Most of urban farming actors are women. Women have the ability to conduct community outreach in the grass root realm as well as competence in organizing society in a persuasive manner. 
In the case study of the Sa'uyunan Women Farmer Group, the empowerment phase has been exceeded from the awareness, capacity building to delegation of authority. The awareness phase was carried out by identifying the motives used by the group in carrying out urban farming. the Sa'uyunan Women Farmer Group is a hobby-based community, and has a lot of free time because the majority of the members of this group do not work elsewhere. After identifying the motives of women farmer, then encourage the optimal implementation of urban farming by inputting the assistance offered by the City Government to sustainable urban farming groups.

The capacity building phase is carried out by strengthening solid institutions and providing training related to agricultural production and processing of post-harvest products. The delegation of authority phase is carried out by creating a community division of labor and product launching carried out by members of the Sauyunan women's farmer group. Because the implementation of urban farming, Sa'uyunan Women's Farmer Group get the benefit from selling vegetables between neighbors outside the Sarijadi area and often they also get the opportunity to associate at markets held by agricultural services and food security. They can also actualize hobbies in making various food products such as ice cream, ginger milk, vegetable pudding which are a source of income.

\section{Discussion}

Referring to Hashemi \& Schuler (1993) defines women empowerment through six areas, namely: (1) Sense of self and future vision including fighting negative husbands' behavior. (2) Mobility and visibility, including how women are treated when they travel. (3) Economic security, including cash income, new skills and knowledge. (4) Status and decision-making power in the household, including making their own purchases. (5) Ability to interact effectively in public spaces. (6) Participation in non-family groups, such as credit programs and solidarity movements.

Based on this perspective, the empowerment of women in urban farming activities in the sauyunan women farmer group fulfills four fields relating to the fulfillment of economic security, status and decisionmaking power in the household, the ability to interact effectively and participate in social movements. Economic security is realized from the sale of fresh horticultural products and processed harvest products. Sa'uyunan women are also able to actualize the status and power of the division of tasks for each division and make decisions about the innovation of processed products and product marketing strategies. The ability to express themselves in public spaces is also obtained by the sa'uyunan women farmer group by participating in various urban farming exhibitions so that group members are able to build networks with partners such as agencies, customers, and other urban farming groups. The sauyunan women farmer group has been transformed into a solidarity movement based on social ties in the local area between neighbors.

\section{Acknowledgment}

We are very thankful for financial support by an Academic Leadership Grants, Universitas Padjadjaran.

\section{References}

1. Adedayo, A., \& Tunde, A. M. (2013). Challenges of women in urban agriculture in kwara State, Nigeria. Sustainable Agriculture Research, 2(5262016-37773)

2. Annes, A., \& Wright, W. (2017). Women Farmers and Agricultural Diversification: Empowerment as a Way of Understanding the Development of Power Relationships Governing Farms in France and the United States. Cahiers Du Genre, 2, 99120.

3. Creswell, J. W. (2014). A concise introduction to mixed methods research. SAGE publications.

4. Edwards, F., Aknolt, P., \& Pakpahan, K. (2014). "Urban Agriculture as a Solution to the Problem of Urbanization in the City of Bandung." Australian Consortium for In-Country Indonesian Studies (ACICIS), Universitas Katolik Parahyangan, 1-45.

5. Elmhirst, R. (2015). Feminist political ecology. The Routledge Handbook of Gender and Development, July, 58-66. https://doi.org/10.4324/9780203383117

6. Febriana, D. (2011). Empowerment : A concept analysis. 1(1), 176-182.

7. Food and Agriculture Organization. of the U. (2019). Country gender assessment of agriculture and the rural sector in Indonesia.

8. Glaser, B. G., \& Strauss, A. L. (2017). Discovery of grounded theory: Strategies for qualitative research. Routledge.

9. Hall, C., Dawson, T. P., Macdiarmid, J. I., Matthews, R. B., \& Smith, P. (2017). The impact of population growth and climate change on food security in Africa: looking ahead to 2050. International Journal of Agricultural Sustainability, 15(2), 124-135. https://doi.org/10.1080/14735903.2017.1293929

10. Hashemi, S. M., \& Schuler, S. R. (1993). Defining and studying empowerment of women: A research note from Bangladesh. Arlington, Virginia: JSI Working Paper, 3.

11. Hovorka, A., Zeeuw, H. de, \& Njenga, M. (2009). Women feeding cities: Mainstreaming gender in urban agriculture and food security. CTA/Practical Action.

12. Khalil Ahmad and Amjad Ali. (2011). Rising Population and Food Insecurity Linkages in Pakistan: Testing Malthusian Population Growth Theory. MPRA Paper No. 71131, 35423.

13. Kutiwa, S., Boon, E., \& Devuyst, D. (2010). Urban agriculture in low income households of Harare: an adaptive response to economic crisis. 
Journal of Human Ecology, 32(2), 85-96. https://doi.org/10.1080/09709274.2010.11906325.

14. Labonte, R. (1989). Community empowerment: The need for political analysis. Canadian Journal of Public Health, 80(2), 87-88.

15. Laverack, G. (2019). Public health: power, empowerment and professional practice. Macmillan International Higher Education.

16. Longwe, S. H. (1998). Education for women's empowerment or schooling for women's subordination? Gender \& Development, 6(2), 1926.

17. Lv, Z., \& Deng, C. (2019). Does women's political empowerment matter for improving the environment? A heterogeneous dynamic panel analysis. Sustainable Development, 27(4), 603612. https://doi.org/10.1002/sd.1926

18. Frona, D., Szenderak, J., and Harangi-Rakos, M. (2019). "The challenge of feeding the World." Sustainability, 11 https://doi.org/10.3390/su11205816

19. Maxwell, D. G. (1995). Alternative food security strategy: A household analysis of urban agriculture in Kampala. World Development, 23(10), 1669-1681. https://doi.org/10.1016/0305750X(95)00073-L

20. Micheletti, M. (2004). Why more women? Issues of gender and political consumerism. Politics, Products, and Markets: Exploring Political Consumerism Past and Present, 245-264.

21. Mougeot, L. J. A. (2000). Urban agriculture: Definition, presence, potentials and risks, and policy challenges. Cities Feeding People Series; Rept. 31.

22. Nugroho, R., \& Wrihatnolo, R. R. (2007). Managing Empowerment. Jakarta: PT. Elex Media Komputindo.

23. Rice, J. S. (2015). Privilege and exclusion at the farmers market: findings from a survey of shoppers. Agriculture and Human Values, 32(1), 21-29. DOI: 10.1007/s10460-014-9513-7

24. Sharma, A., Dua, S., \& Hatwal, V. (2012). Micro enterprise development and rural women entrepreneurship: way for economic empowerment. Arth Prabhand: A Journal of Economics and Management, 1(6), 114-127.

25. Tefft, J., Jonasova, M., Adjao, R., \& Morgan, A. (2017). Food Systems for an Urbanizing World. Food Systems for an Urbanizing World. https://doi.org/10.1596/32502

26. Trauger, A. (2004). 'Because they can do the work': Women farmers in sustainable agriculture in Pennsylvania, USA. Gender, Place \& Culture, 11(2), 289-307. https://doi.org/10.1080/0966369042000218491.

27. Van Veenhuizen, R., \& Danso, G. (2007). Profitability and sustainability of urban and periurban agriculture (Vol. 19). Food \& Agriculture org. 